\title{
RELATIONSHIP BETWEEN GENETIC AND ENVIRONMENTAL CHARACTERISTICS OF LITHUANIAN POPULATIONS OF PURPLE LOOSESTRIFE (LYTHRUM SALICARIA)
}

\author{
Lina JOCIENE் (1) 1, Edvina KROKAITE் ${ }^{1}$, Dinara SHAKENEVA®1,

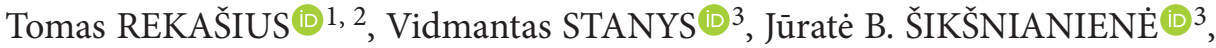 \\ Donatas ŽVINGILA ${ }^{4}{ }^{4}$, Algimantas PAULAUSKAS®1, Eugenija KUPČINSKIENE் ${ }^{\circledR}{ }^{*}$ \\ ${ }^{1}$ Department of Biology, Faculty of Nature Sciences, Vytautas Magnus University, \\ Universiteto g. 10, LT-53661 Akademija, Kaunas distr., Lithuania \\ ${ }^{2}$ Department of Mathematical Statistics, Vilnius Gediminas Technical University, Vilnius, Lithuania \\ ${ }^{3}$ Lithuanian Research Centre for Agriculture and Forestry, Institute of Horticulture, \\ Kauno g. 30, LT-54333 Babtai, Kaunas distr., Lithuania \\ ${ }^{4}$ Institute of Biosciences, Life Sciences Center, Vilnius University, Sauletekio al. 7, LT-10257 Vilnius, Lithuania
}

Received 23 June 2021; accepted 13 October 2021

\begin{abstract}
Highlights
- Genetic diversity of Lithuanian populations of Lythrum salicaria was relatively low.

- Molecular variance within populations of $L$. salicaria was much higher compared to variability among populations.

- Hierarchical analysis of molecular variance showed significant differences among populations belonging to distinct river basins.

- Percentage of polymorphic loci for populations besides regulated fragments of the rivers was lower compared to that for populations growing along natural riverbeds.
\end{abstract}

\begin{abstract}
The present study evaluated genetic diversity of Lithuanian populations of Lythrum salicaria in relation to parameters of riparian environment. Growing along Nemunas, Seaside and Lielupe river basins, 15 populations were examined using amplified fragment length polymorphism markers. Molecular data were related to the river basins, type of land use and cover, natural vice versa regulated fragments of the rivers. Population mean genetic diversity parameters were as follows: percentage of polymorphic loci (57.2), index of Nei's gene diversity, $h(0.183)$, polymorphisme information content (0.218). Mantel test revealed correlation $\left(\mathrm{R}^{2}=0.0986, \mathrm{p}=0.01\right)$ between genetic and geographic distance of populations. Greater genetic diversity within, rather than among populations $\left(\Phi_{P T}=0.213\right)$ was observed. According to the Bayesian clustering, studied populations are admixtures of two gene pools. Analysis of molecular variance revealed significant differentiation between populations belonging to distinct river basins, between populations from natural vs. regulated fragments of the rivers.
\end{abstract}

Keywords: AFLP molecular markers, riparian ecosystem, aliens, invasions, plant diversity, native distribution, river regulations, land use, aquatic plants.

\section{Introduction}

Riparian habitats are very complex and important part of terrestrial ecosystem. Their plants are distinct by big variety of life forms, and are of high economic, ecological also aesthetic value (Riis et al., 2020; Nawieśniak-Caesar et al., 2019). A major concern of such areas is biodiversity, affected by increasing fluctuations of climate (Kiesel et al., 2019), multi-component chemical pollution (Yoshikawa et al., 2015; Stella \& Bendix, 2019) and mechanical interventions (Anderson et al., 2018). When compared to land plants, riparian vegetation is exposed to a much stronger effect of anthropogenic factors (Kalusová et al., 2017). The current millennium focuses on the state of threatened

${ }^{*}$ Corresponding author. E-mail: e.kupcinskiene@gmail.com 
species or invasive organisms (Dudgeon et al., 2006; Richardson et al., 2007). In contrast to these groups, naturally occurring common species do not receive adequate attention (Hejda \& de Bello, 2013). It could be true for populations of riparian species widely growing in pristine European territories of temperate climate zone although invasive in some other continents (Kalusová et al., 2017). Under various scenarios of ongoing climatic change, information about diversity of plants, sampled within natural distribution range, is crucial for understanding of species behavior potentials. In special, information about genetic traits might be valuable tool explaining possible mechanisms of invasiveness success (Richards et al., 2012).

Belonging to Rosid clade, Myrtales order, Lythraceae family (with 31 genera), purple loosestrife (Lythrum salicaria L.) is one out of 34 species of Lythrum genera ( $\mathrm{Gu}$ et al., 2019). It is tall perennial herb $(50-150 \mathrm{~cm})$ with showy arranged in racemes flowers of bright purple, red or pink color (Anderson \& Ascher, 1993; Thompson et al., 1987; Migliore et al., 2010). It is polyploid, very conservative according to chloroplast genome (Gu et al., 2019), outcrossing species, pollinated by bees, butterflies, one individual producing up to $3 \mathrm{mln}$ seeds inclosed into capsules (Thompson et al., 1987).

Lythrum salicaria is a species of the Northern Hemisphere with a broad native distribution in Europe, the Mediterranean, North Africa, northern and western Asia and the Himalayas (Thompson et al., 1987). This species is widely investigated along his invasive distribution range in North America, and natural areas of West Europe (Houghton-Thompson et al., 2005). Information about the species in more northern-eastern territories of Europe, including Baltic States, is still missing; despite L. salicaria is rather common plant of wetlands of these areas. In the former decade performed studies of aquatic macrophytes (including $L$. salicaria) of Lithuania concern only parameters of phytocenology and abiotic environment of this species (Zviedre et al., 2015). Fact about hormetic response of $L$. salicaria (Migliore et al., 2007) shows that data from one region cannot be simply transferred to the other, and wider assessments are required to evaluate this pygmalion species.

Among riparian species $L$. salicaria is distinct by number of very special biological-ecological features such as tristily protecting from self-pollination (Anderson \& Ascher, 1995), ability to survive in fluctuating water supply (i.e. amphibian type of life; Hamann \& Puijalon, 2013), relatedness to moderate salinity of the environment (Li \& Yao, 2011; Migliore et al., 2010). In addition, L. salicaria is valuable species for remediation: 10 month simulation of the domestic wastewater in constructed wetlands of 4 aquatic species (Camacho et al., 2007) showed the greater growth of $L$. salicaria and more efficient removal of total nitrogen compared to the other tested plants. L. salicaria is important as melliferous, medicinal plant, showing antimicrobial, antioxidative and genotoxic effects (Rauha et al., 2000). Relying on numerous tests, in Southern
Europe L. salicaria was among 7 the best out of 127 plants which might have ethnobotanical value for better human aging (The Local Food-Nutraceuticals Consortium, 2005).

Data concerning genetic variation within species may have predictive value for ecosystems, with importance for short-term management strategies and longer-term approaches, for example in mitigation of climate change. Already three decades molecular methods remain among the most reliable tools for information sets about population diversity issues (Guichoux et al., 2011). Inter simple sequence repeats (ISSR), microsatellites (SSR) and amplified fragment length polymorphism (AFLP) markers are the most frequently used tools for examination of genetic diversity of populations of macrophytes (Lambertini et al., 2010; Anderson et al., 2018; Vyšniauskienè et al., 2020; Fan et al., 2021), as well as for detection of introgression (Bradley et al., 2013; Butkuvienè et al., 2017), linking phenotyphic plasticity to genetic variation (Wennersten \& Forsman, 2012; Forsman, 2014). Before initiation of present study, American populations of L. salicaria were tested employing AFLP markers, and related data concerning genetic diversity of this species in Europe were limited to West regions (Houghton-Thompson et al., 2005; Chun et al., 2009). Pollen and seed dispersal of riparian vegetation is strongly related to the watercourse (Nazareno et al., 2021). Only pilot studies have been done examining genetic diversity differences of riparian populations depending on river basins, land use type, or river regulation (Lamote et al., 2002; Anderson et al., 2018).

The present study is aimed at comparison of genetic diversity of Lithuanian populations of purple loosestrife (L. salicaria) in relation to parameters of riparian environment.

\section{Materials and methods}

\subsection{Sites and sampling}

For present study 15 sites were selected along 3 river basins in Lithuania: Nemunas (Nem-Dru, Nem-Čio, Nem-Kau, Ner-Kau, Nev-Kèd, Nem-Jur, Lei-Nem), Seaside rivers (Rąž-Upp, Rąž-Mid, Rąž-Low, Dit-Nmr, ŠveŠve) and Lielupė (Šve-Žag, Apa-Bir, Kru-Pak; Figure 1; Table 1). Sampling area extended between $54^{\circ} 01^{\prime} 12.9^{\prime \prime}$ and $56^{\circ} 21^{\prime} 36.6^{\prime \prime}$ of Northern latitude, $21^{\circ} 03^{\prime} 21.8^{\prime \prime}$ and $24^{\circ} 45^{\prime} 57.8^{\prime \prime}$ of Eastern longitude.

Sampling was carried out in the $1^{\text {st }}$ ten-day period of August 2015, at the time of the most intensive bloom of L. salicaria. For analyses at each site 6 plants were collected, selecting individuals growing $>15 \mathrm{~m}$ apart. Fully developed, healthy (without visible mechanical or biotic damages) leaves from the upper part of the main axis of L. salicaria were collected as it is done earlier with some other perennial herbs (Anderson et al., 2018). Leaves of the plants were enclosed into separate bags and within cool box transported to the laboratory, until DNA extraction keeping specimens frozen. Before DNA extraction leaves were washed with distilled water. 


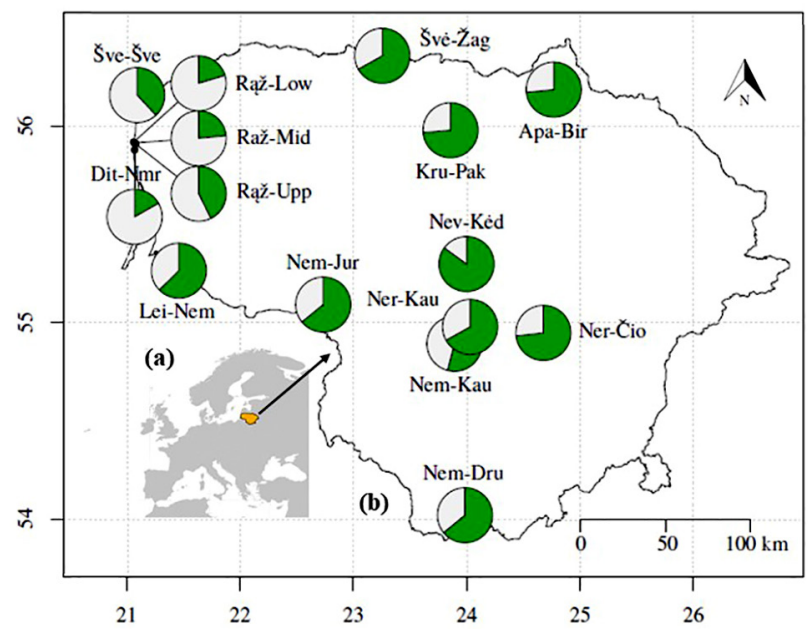

Figure 1. Geographic location of Lithuanian populations of Lythrum salicaria based on the data of Bayesian analysis in STRUCTURE: clustering plot of populations using pie diagrams (two gene pools labelled in white and green) to indicate the proportion of membership of each $\mathrm{K}=2$ clusters in the populations

\subsection{DNA extraction}

Genomic DNA was isolated using the modified CTAB method (Doyle \& Doyle, 1990; Kupcinskiene et al., 2013). The leaves $(0.15 \mathrm{~g})$ were ground in liquid nitrogen and transferred into $1 \mathrm{ml}$ sorbitol buffer (prepared in the following proportions: $3.5 \mathrm{ml}$ of $1 \mathrm{M}$ sorbitol, $1 \mathrm{ml}$ of $1 \mathrm{M}$ Tris-HCl, $0.1 \mathrm{ml}$ of $0.5 \mathrm{M}$ EDTA, $0.1 \mathrm{~g}$ PVP, and $0.11 \mathrm{ml}$ of $\beta$-merkaptoethanol ( $\geq 99 \%)$ ). To remove more polysaccharides, wash with sorbitol buffer was repeated for several times (Souza et al., 2012). For DNA extraction, samples were filled with $800 \mu$ l extraction buffer, prepared mixing $0.4 \mathrm{ml} 0.5 \mathrm{M}$ EDTA, $1 \mathrm{ml}$ of $1 \mathrm{M}(\mathrm{pH}=8.0)$ TRIS$\mathrm{HCl}$ (Amresco, USA), $2.75 \mathrm{ml} 5 \mathrm{M} \mathrm{NaCl}, 2 \mathrm{ml}$ (10\%) CTAB (Carl Roth GmbH + Co.KG Germany), $0.02 \mathrm{ml} \beta$-mercaptoethanol (BME, Carl Roth GmbH+Co.KG, Germany), $10 \mathrm{mg}$ polyvinylpyrrolidone-30 (PVP-30; Carl Roth GmbH + Co.KG, Germany), and $1.83 \mathrm{ml}$ distilled water. The quantity and quality of the samples of extracted genomic DNA were assessed by electrophoresis (1\% agarose gel) and by UV spectrophotometer (BioSpec-Nano, Shimadzu, USA).

\subsection{AFLP analysis}

AFLP fingerprinting followed the protocols of Vos et al. (1995) and Chun et al. (2009). Double-stranded adaptors were prepared from the complementary single-stranded oligonucleotides: 5'-CTCGTATACTGCGTACC-3' (forward) and 5'-AATTGGTACGCAGTA-3' (reverse) for the EcoRI adapter pair, and 5'-GACGATGAGTCCTGAG-3' (forward) and 5'-CTACTCAGGACTCAT-3' (reverse) for the MseI adapter pair.

Performing restriction/ligation reaction, $6 \mu \mathrm{l}$ (200 ng) of DNA was added to $5 \mu \mathrm{l}$ of restriction/ligation reaction mix, containing $0.55 \mu \mathrm{l}(1 \mathrm{mg} / \mathrm{ml}) \mathrm{BSA}$ (Thermo Scientific, Lithuania), $1.1 \mu \mathrm{l}$ of $5 \mathrm{X}$ T4 DNA Ligase buffer (Invitrogen, USA), $1.1 \mu \mathrm{l}$ of $0.5 \mathrm{M} \mathrm{NaCl}$ (Invitrogen by Thermo Fisher Scientific, Lithuania), $0.05 \mu \mathrm{l}$ of (10 $000 \mathrm{U} / \mathrm{ml})$ EcoRI and $0.1 \mu \mathrm{l}$ of $(10000 \mathrm{U} / \mathrm{ml})$ Mse I restriction enzymes (New England BioLabs, UK), $0.05 \mu \mathrm{l}$ of $(2000000 \mathrm{U} / \mathrm{ml}) \mathrm{T} 4$ DNA Ligase (Invitrogen, USA), $1 \mu \mathrm{l}$ of ( $50 \mathrm{pmol} / \mu \mathrm{l}) \mathrm{Mse}$ I adapter and $1 \mu \mathrm{l}$ of $(5 \mathrm{pmol} / \mu \mathrm{l})$ Eco RI adapter (Invitrogen by Thermo Fisher Scientific, Lithuania), $0.05 \mu \mathrm{l}$ of distilled water. Samples were incubated at $37^{\circ} \mathrm{C}$ for $2 \mathrm{~h}$. Five $\mu \mathrm{L}$ of restriction/ligation reaction product was diluted by $5 \mu$ lof the distilled water.

Table 1. Titles, geographic location and environment characteristics of Lithuanian populations of purple loosestrife (Lythrum salicaria)

\begin{tabular}{|c|c|c|c|c|c|c|c|}
\hline River & River basin & Location & $\begin{array}{l}\text { Acronym of } \\
\text { population }\end{array}$ & Latitude $\left({ }^{\circ} \mathrm{N}\right)$ & Longitude $\left({ }^{\circ} \mathrm{E}\right)$ & $\begin{array}{l}\text { Land cover } \\
\text { type }\end{array}$ & River status \\
\hline Nemunas & Nemunas & Druskininkai & Nem-Dru & $54^{\circ} 01^{\prime} 12.9^{\prime \prime}$ & $23^{\circ} 58^{\prime} 53.9^{\prime \prime}$ & AGR & $\mathrm{N}$ \\
\hline Neris & Nemunas & Čiobiškis & Ner-Čio & $54^{\circ} 56^{\prime} 55.9^{\prime \prime}$ & $24^{\circ} 40^{\prime} 28.0^{\prime \prime}$ & AGR & $\mathrm{N}$ \\
\hline Neris & Nemunas & Kaunas & Ner-Kau & $54^{\circ} 58^{\prime} 46.2^{\prime \prime}$ & $24^{\circ} 01^{\prime} 37.7^{\prime \prime}$ & AGR & $\mathrm{N}$ \\
\hline Nemunas & Nemunas & Kaunas & Nem-Kau & $54^{\circ} 53^{\prime} 35.9^{\prime \prime}$ & $23^{\circ} 53^{\prime} 21.0^{\prime \prime}$ & ART & $\mathrm{N}$ \\
\hline Nevèžis & Nemunas & Kèdainiai & Nev-Kèd & $55^{\circ} 17^{\prime} 58.3^{\prime \prime}$ & $23^{\circ} 59^{\prime} 45.5^{\prime \prime}$ & AGR & $\mathrm{N}$ \\
\hline Nemunas & Nemunas & Jurbarkas & Nem-Jur & $55^{\circ} 05^{\prime} 35.1^{\prime \prime}$ & $22^{\circ} 43^{\prime} 48.9^{\prime \prime}$ & AGR & $\mathrm{N}$ \\
\hline Leitè & Nemunas & Sausgalviai & Lei-Nem & $55^{\circ} 15^{\prime} 57.6^{\prime \prime}$ & $21^{\circ} 27^{\prime} 18.4^{\prime \prime}$ & FOR & $\mathrm{R}$ \\
\hline Rąžè & Seaside rivers & Palanga & Rąž-Upp & $55^{\circ} 54^{\prime} 39.8^{\prime \prime}$ & $21^{\circ} 04^{\prime} 28.9^{\prime \prime}$ & ART & $\mathrm{R}$ \\
\hline Rąžè & Seaside rivers & Palanga & Raž-Mid & $55^{\circ} 54^{\prime} 59.3^{\prime \prime}$ & $21^{\circ} 03^{\prime} 56.4^{\prime \prime}$ & ART & $\mathrm{R}$ \\
\hline Rąžè & Seaside rivers & Palanga & Rąž-Low & $55^{\circ} 55^{\prime} 14.1^{\prime \prime}$ & $21^{\circ} 03^{\prime} 21.8^{\prime \prime}$ & ART & $\mathrm{R}$ \\
\hline Ditch & Seaside rivers & Nemirsèta & Dit-Nmr & $55^{\circ} 52^{\prime} 50.1^{\prime \prime}$ & $21^{\circ} 03^{\prime} 50.2^{\prime \prime}$ & ART & $\mathrm{R}$ \\
\hline Šventoji & Seaside rivers & Šventoji & Šve-Šve & $56^{\circ} 02^{\prime} 02.1^{\prime \prime}$ & $21^{\circ} 05^{\prime} 12.3^{\prime \prime}$ & AGR & $\mathrm{N}$ \\
\hline Švètė & Lielupė & Žagarè & Švè-Žag & $56^{\circ} 21^{\prime} 36.6^{\prime \prime}$ & $23^{\circ} 15^{\prime} 07.5^{\prime \prime}$ & ART & $\mathrm{N}$ \\
\hline Apaščia & Lielupè & Biržai & Apa-Bir & $56^{\circ} 11^{\prime} 16.7^{\prime \prime}$ & $24^{\circ} 45^{\prime} 57.8^{\prime \prime}$ & ART & $\mathrm{N}$ \\
\hline Kruoja & Lielupè & Pakruojis & Kru-Pak & $55^{\circ} 58^{\prime} 52.2^{\prime \prime}$ & $23^{\circ} 51^{\prime} 15.8^{\prime \prime}$ & ART & $\mathrm{N}$ \\
\hline
\end{tabular}

Note: Land cover type: AGR - agricultural area, ART - artificial area, FOR - forest and semi-natural areas; River status: $\mathrm{N}$ - natural, $\mathrm{R}$ - regulated. 
For the preselective polymerase chain reaction (PCR), $4 \mu \mathrm{l}$ of the ligation product was added to $16 \mu \mathrm{l}$ of a preselective PCR mix, consisting of $2 \mu \mathrm{l} 10 \mathrm{X}$ Dream Taq PCR buffer (Thermo Scientific, Lithuania), $2 \mu \mathrm{l}$ of $2 \mathrm{mM}$ dNTPs (Thermo Scientific, Lithuania), $0.5 \mu \mathrm{l}(30 \mathrm{ng} / \mu \mathrm{l})$ of each preselective primer and $0.16 \mu \mathrm{l}$ of $(5 \mathrm{U} / \mu \mathrm{l})$ Dream Taq DNA polymerase (Thermo Scientific, Lithuania), $10.84 \mu \mathrm{l}$ $\mathrm{H}_{2} \mathrm{O}$. Sequences of preselective primers were EcoRI_A: 5'-TACTGCGTACCAATTCA-3' and MseI_C: 5'-GATGAGTCCTGAGTAAC-3'. Parameters of preselective PCR reaction were as follows: $75^{\circ} \mathrm{C}$ extension for $2 \mathrm{~min}$ followed by 20 cycles of $94{ }^{\circ} \mathrm{C}$ for $30 \mathrm{~s}, 56^{\circ} \mathrm{C}$ for $35 \mathrm{~s}, 72^{\circ} \mathrm{C}$ for $1 \mathrm{~min}$, finishing with one cycle of $60^{\circ} \mathrm{C}$ for $30 \mathrm{~min}$. Electrophoresis of PCR product was run on a $1 \%$ TBEagarose gels. To the remaining $10 \mu \mathrm{L}$ product of preselective amplification $40 \mu \mathrm{L}$ of $\mathrm{H}_{2} \mathrm{O}$ was added.

For the selective PCR, $1 \mu \mathrm{l}$ of diluted preselective PCR product was added to $3.50 \mu \mathrm{L}$ of the selective PCR mix. Selective PCR mix was prepared in following way: $0.35 \mu \mathrm{l}$ 10X Green PCR buffer (Invitrogen by Thermo Fisher Scientific, Lithuania), $0.105 \mu \mathrm{l}$ of $\mathrm{MgCl}_{2}$ (50 mM; Invitrogen by Thermo Fisher Scientific, Lithuania), $0.07 \mu \mathrm{l}$ of dNTPs (10 mM; Thermo Fisher Scientific, Lithuania), $0.105 \mu \mathrm{KB}$ Extender (Invitrogen by Thermo Fisher Scientific, Lithuania), $0.6 \mu \mathrm{l}$ one out of four EcoRI labelled (6-FAM, VIC and NED) selective primers, $0.6 \mu \mathrm{L}$ of MseI unlabelled primer, $0.014 \mu \mathrm{l}$ of Platinum Taq DNA polymerase $(5 \mathrm{U} / \mu \mathrm{l}$; Invitrogen by Thermo Fisher Scientific, Lithuania), adding distilled water to a final volume of $3.50 \mu \mathrm{l}$.

For selective PCR four primer pairs were used: EcoRI + AGC (6-FAM), EcoRI + ACG (VIC), EcoRI + ACA (NED) and EcoRI + AAC (6-FAM), each paired with MseI + CAA (Chun et al., 2009). The PCR reactions was performed with following program: one cycle of $94^{\circ} \mathrm{C}$ for $2 \mathrm{~min}$, one annealing cycle of $94{ }^{\circ} \mathrm{C}$ for $30 \mathrm{~s}, 65^{\circ} \mathrm{C}$ for $30 \mathrm{~s}$ and $72^{\circ} \mathrm{C}$ for $2 \mathrm{~min}$, followed by nine cycles of $94^{\circ} \mathrm{C}$ for $30 \mathrm{~s}, 64^{\circ} \mathrm{C}$ for $30 \mathrm{~s}$ touch-down programme of a $1{ }^{\circ} \mathrm{C}$ decrease in annealing temperature per cycle and $72{ }^{\circ} \mathrm{C}$ for $2 \mathrm{~min}$, followed by 35 cycles of $94^{\circ} \mathrm{C}$ for $30 \mathrm{~s}, 56^{\circ} \mathrm{C}$ for $30 \mathrm{~s}$ and $72{ }^{\circ} \mathrm{C}$ for $2 \mathrm{~min}$, and a final extension at $60^{\circ} \mathrm{C}$ for $30 \mathrm{~min}$.

The fluorescence-labelled selective amplification products were separated using automated capillary gel electrophoresis (Genetic analyzer 3130; Applied Biosystems, Germany) with LIZ-500 standard (Applied Biosystems, Germany). Data were analyzed by GeneMapper v. 4.0 (Applied Biosystems, Germany). The four primer combinations applied to 90 individuals from 15 populations, generated 1452 fragments, ranging from 50 to $500 \mathrm{bp}$. Reproducibility of the data was checked repeating analyses of occasionally selected individuals from all populations (Frercks et al., 2014).

Discerning the possible effects of features of the rivers and their environment on genetic diversity of the plants, populations were grouped according to the 1 ) river basins: Nemunas, Seaside and Lielupe; 2) location of populations in respect to position in Lithuania: south-west, west and northern; 3 ) type of land cover: artificial (ART), agricultural (AGR) and forest, semi-natural (further in the text named under forest areas, abbr. FOR), employing CORINE (classification system of COoRdinate Information on the Environment) Land Cover database classification level 1) available for 2006 (CORINE Land Cover [CLC], 2006); 4) natural and regulated fragments of the rivers. Regulated fragments of the rivers were identified based on hydrological data of Lithuania (Gailiušis et al., 2001; Jablonskis et al., 2007; for more details, see Krokaitè et al., 2019).

\subsection{Statistical analyses}

DNA fragments obtained for each AFLP loci were scored in a binary format as present (1) or absent (0). Molecular diversity parameters within populations were calculated using PopGene v. 1.31 (Yeh et al., 1999). Populations were compared according to Nei's unbiased genetic distances (GD; Nei, 1978). The polymorphism information content (PIC) value was calculated following recommendations of Anderson et al. (1993), Chun et al. (2009): PIC $=2 \mathrm{f}(1-\mathrm{f})$, where $\mathrm{f}-$ the frequency of the marker fragments, which were present and $1-\mathrm{f}$ the frequency of marker fragments, which were absent. To estimate variance components partitioned within populations and among populations AMOVA in Genalex (Excoffier \& Lischer, 2010) was performed. In addition, hierarchic AMOVA was carried out grouping populations according to their geographic region or growth density. Correlations between genetic and geographical distances of populations by Mantel test (9999 permutations; Mantel, 1967 ) and principal coordinate analysis (PCoA) were done in GENALEX program, v. 6.5 (Peakall \& Smouse, 2012). A Bayesian cluster analysis was performed using admixture ancestry model within STRUCTURE v. 2.3.3 (Pritchard et al., 2000; Falush et al., 2003). The $\Delta K$ method of Evanno et al. (2005) was used. Probable number of population clusters $(K)$ was set from 1 to 15 . $K$-values were simulated across 20 replicate runs of 1000000 iterations after a burn-in period of 100000 .

\section{Results}

From the four selected AFLP primer pairs, 1452 fragments were scored analyzing 90 individuals of Lithuanian populations of L. salicaria. For studied populations all AFLP primer pairs generated polymorphic loci ranging in the interval $35.0-65.4 \%$, with a mean number per population $57.2 \%$ (Table 2). The lowest polymorphism of DNA was documented for populations of Seaside rivers (Dit-Nem, Rąž-Low, Šve-Šve, respectively 35.0\%, 45.3\% and 50.5\%). The populations with the highest percentage of DNA polymorphic loci were not related to the same river basin or geographic region of Lithuania (Kru-Pak, NemDru and Apa-Bir, respectively 65.4\%, 65.2\% and 65.0\%, respectively). 
Table 2. AFLP loci based genetic diversity parameters of 15 Lithuanian populations of Lythrum salicaria

\begin{tabular}{|l|c|c|c|c|}
\hline $\begin{array}{c}\text { Popula- } \\
\text { tions }\end{array}$ & $\begin{array}{c}\% \\
\mathrm{P}\end{array}$ & $\begin{array}{c}I \\
\text { mean } \pm \text { SE }\end{array}$ & $\begin{array}{c}h \\
\text { mean } \pm \text { SE }\end{array}$ & PIC \\
\hline Nem-Dru & 65.15 & $0.314+0.007$ & $0.204+0.005$ & 0.247 \\
\hline Ner-Čio & 63.57 & $0.318+0.007$ & $0.209 \pm 0.005$ & 0.243 \\
\hline Ner-Kau & 61.36 & $0.313+0.007$ & $0.207 \pm 0.005$ & 0.237 \\
\hline Nem-Kau & 61.29 & $0.287+0.007$ & $0.185 \pm 0.005$ & 0.228 \\
\hline Nev-Kèd & 61.02 & $0.329+0.008$ & $0.221 \pm 0.005$ & 0.235 \\
\hline Nem-Jur & 55.03 & $0.274+0.007$ & $0.179 \pm 0.005$ & 0.212 \\
\hline Lei-Nem & 58.61 & $0.288+0.007$ & $0.188 \pm 0.005$ & 0.223 \\
\hline Rąž-Upp & 55.51 & $0.262+0.007$ & $0.168 \pm 0.005$ & 0.215 \\
\hline Rąž-Mid & 52.55 & $0.233+0.006$ & $0.147 \pm 0.004$ & 0.196 \\
\hline Rąž-Low & 45.32 & $0.186+0.006$ & $0.114 \pm 0.004$ & 0.158 \\
\hline Dit-Nmr & 34.99 & $0.172+0.007$ & $0.113+0.005$ & 0.134 \\
\hline Šve-Šve & 50.48 & $0.247+0.007$ & $0.161 \pm 0.005$ & 0.196 \\
\hline Švė-Žag & 62.33 & $0.308+0.007$ & $0.201 \pm 0.005$ & 0.242 \\
\hline Apa-Bir & 65.01 & $0.337+0.007$ & $0.223 \pm 0.005$ & 0.251 \\
\hline Kru-Pak & 65.43 & $0.338+0.007$ & $0.225 \pm 0.005$ & 0.252 \\
\hline Mean & 57.18 & $0.280+0.002$ & $0.183 \pm 0.001$ & 0.218 \\
\hline
\end{tabular}

Note: \% P - percentage of polymorphic DNA loci; I - Shannon's information index; SE - standard error; $h$ - index of Nei's gene diversity. Number of individuals for each population - 6; PIC Polymorphism information content.

The lowest and the highest values of the Shannon's information index also of the Nei's genetic diversity were for the same populations like in case of polymorphic DNA percentage. The lowest and the highest value of the Shannon's information index per population (Kru-Pak and Dit-Nmr populations) differed 1.91 times and ranged in the interval 0.172-0.338. Extreme values of Nei's genetic diversity for these populations differed 1.99 times, ranging in the interval 0.113-0.225.

Geographic distances between populations ranged $0.8-290.1 \mathrm{~km}$ (Table 3). The shortest distances were between Seaside populations (Rąž-Mid-Rąž-Low) and the longest distances were between Seaside and Nemunas or Lielupe populations (Šve-Šve-Nem-Dru).

Genetic distances between pairs of Lithuanian populations of $L$. salicaria ranged in the interval 0.068-0.193, mean being 0.127 . In most cases genetic distances corresponded geographic distances: Nev-Kèd population of Lielupe basin had the biggest genetic distances with the populations of the Seaside rivers basin and the shortest genetic distances were between populations of Seaside rivers basin, located in the shortest distance. Respectively, Mantel test (Mantel, 1967) revealed significant association between Nei's based genetic distances and geographical distances of $L$. salicaria populations (Figure 2).

Hereby Mantel test indicated that genotypes become more different with geographic distance. Based on the nonhierarchical AMOVA of data set of 15 populations of $L$. salicaria, observed molecular variance was higher within $(79 \%)$ rather than among populations $(21 \%),(\mathrm{Ta}-$ ble 4). The level of genetic variation among populations was highly significant $(p \leq 0.001)$.

Low significant $(\mathrm{p}<0.001)$ proportion of variation (5\%) was explained by differences among groups of populations classified into Nemunas, Seaside and Lielupe river basins (Table 5A). The same extent variation was true among groups reflecting geographic location of populations (Table 5B). An extremely low, although significant $(\mathrm{p}<0.043)$ proportion of variation $(1 \%)$ was explained by

Table 3. AFLP loci based genetic (lower triangle; Nei, 1978) and geographical distances (upper triangle $\mathrm{km}$ ) between 15 Lithuanian populations of Lythrum salicaria

\begin{tabular}{|l|l|c|c|c|c|c|c|c|c|c|c|c|c|c|c|}
\hline \multicolumn{10}{|c|}{} \\
\hline
\end{tabular}




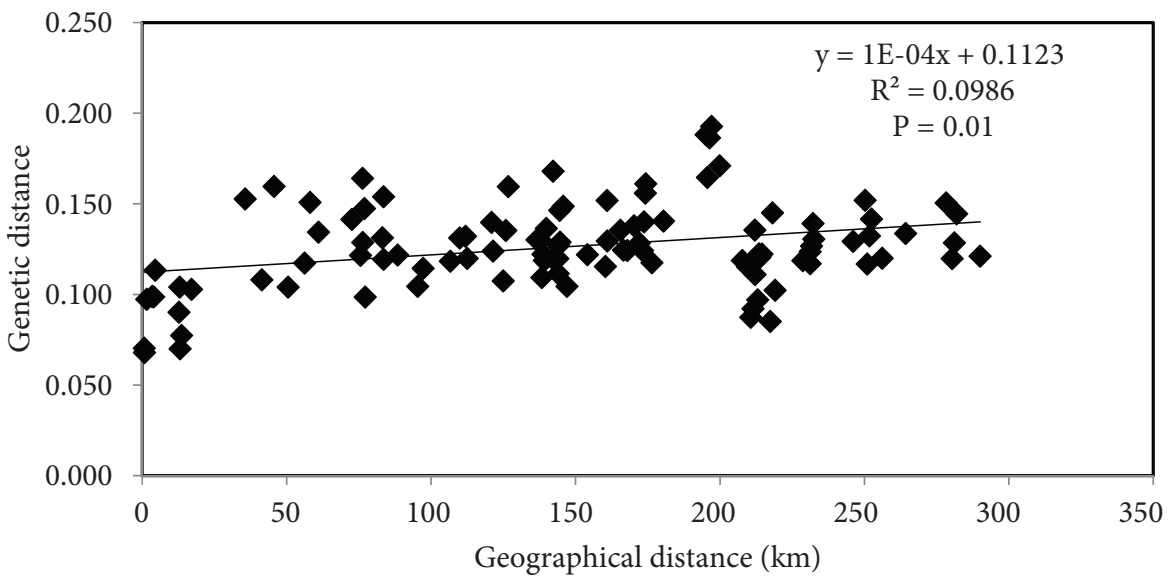

Figure 2. AFLP loci-based Mantel test of correlation between Nei's genetic and geographic distances for 15 Lithuanian populations of L. salicaria

Table 4. AFLP loci based molecular variance (AMOVA) of Lithuanian populations of Lythrum salicaria

\begin{tabular}{|l|c|c|c|c|c|c|c|}
\hline \multicolumn{1}{|c|}{ Source } & $\mathrm{df}$ & $\mathrm{SS}$ & $\mathrm{MS}$ & Est. Var. & $\%$ & $\Phi_{P T}$ & $\mathrm{p}$ \\
\hline Among populations & 14 & 6975 & 498 & 51.40 & 21 & 0.213 & 0.001 \\
\hline Within populations & 75 & 14239 & 190 & 189.85 & 79 & & \\
\hline Total & 89 & 21214 & & 241.24 & 100 & & \\
\hline
\end{tabular}

Note: $\mathrm{df}$ - degrees of freedom, SS - sum of squares, MS - mean squares, Est. Var. - estimated variability, \% - percentage of variation, $\Phi_{P T}-$ genetic differentiation among populations, $\mathrm{p}$ - probability of differences, $\mathrm{p}<.01$; significance levels are based on 1,000 permutations.

Table 5. AFLP loci based hierarchical analysis of molecular variance (AMOVA) among populations of Lythrum salicaria: 1) belonging to the different river basins, 2) neighboring areas of different types of land cover, 3) belonging to natural or regulated river fragments (for details, see Table 1)

\begin{tabular}{|c|c|c|c|c|c|c|c|}
\hline Source & $\mathrm{df}$ & SS & MS & Est. Var. & $\%$ & $\Phi$ & $\mathrm{p}$ \\
\hline \multicolumn{8}{|l|}{ A } \\
\hline Among populations of Nemunas, Seaside and Lielupe basins & 2 & 1639 & 819 & 13.19 & 5 & $\Phi_{P T}=0.054$ & 0.001 \\
\hline Among populations & 12 & 5336 & 445 & 42.48 & 17 & $\Phi_{P R}=0.183$ & 0.001 \\
\hline Within populations & 75 & 14239 & 190 & 189.85 & 77 & $\Phi_{R T}=0.227$ & 0.001 \\
\hline Total & 89 & 21214 & & 245.5 & 100 & & \\
\hline \multicolumn{8}{|l|}{ B } \\
\hline Among North Lithuania, West Lithuania, South-West Lithuania & 2 & 1415 & 707 & 12.20 & 5 & $\Phi_{R T}=0.050$ & 0.001 \\
\hline Among populations & 12 & 4152 & 346 & 22.90 & 9 & $\Phi_{P R}=0.099$ & 0.001 \\
\hline Within populations & 75 & 15647 & 209 & 208.63 & 86 & $\Phi_{P T}=0.144$ & 0.001 \\
\hline Total & 89 & 21214 & & 243.73 & 100 & & \\
\hline \multicolumn{8}{|l|}{$\mathrm{C}$} \\
\hline $\begin{array}{l}\text { Among populations besides agricultural, artificial, and } \\
\text { forested areas }\end{array}$ & 2 & 1111 & 556 & 2.69 & 1 & $\Phi_{P T}=0.011$ & 0.041 \\
\hline Among populations & 12 & 5864 & 489 & 49.81 & 21 & $\Phi_{P R}=0.208$ & 0.001 \\
\hline Within populations & 75 & 14239 & 190 & 189.85 & 78 & $\Phi_{R T}=0.217$ & 0.001 \\
\hline Total & 89 & 21214 & & 242.35 & 100 & & \\
\hline \multicolumn{8}{|l|}{$\mathrm{D}$} \\
\hline $\begin{array}{l}\text { Among populations from natural and regulated river } \\
\text { fragments }\end{array}$ & 1 & 806 & 806 & 8.29 & 3 & $\Phi_{P T}=0.034$ & 0.001 \\
\hline Among populations & 13 & 6169 & 475 & 47.45 & 19 & $\Phi_{P R}=0.200$ & 0.001 \\
\hline Within populations & 75 & 14239 & 190 & 189.85 & 77 & $\Phi_{R T}=0.227$ & 0.001 \\
\hline Total & 89 & 21214 & & 245.58 & 100 & & \\
\hline
\end{tabular}

Note: $\mathrm{df}$ - degrees of freedom, SS - sum of squares, MS - mean squares, Est. Var. - estimated variability, \% - percentage of variation, $\mathrm{p}$ - probability of differences, $\mathrm{p}<.01 ; \Phi$ - pairwise population genetic distances: $\Phi_{P T}, \Phi_{P R}, \Phi_{R T}$ - proportion of variance among the river basins/land cover types/river fragments, among populations and within populations, respectively $(\mathrm{p}<0.001)$. 
differences among groups of populations classified according to land cover types (agricultural, artificial, forest and semi-natural areas; Table 5C). Low significant $(\mathrm{p}<0.001)$ proportion of variation (4\%) was explained by differences among groups of populations classified to natural and regulated river fragments (Table 5D). Polymorphic loci percentage of populations grouped from regulated river fragments was lower $(56.1 \%)$ than populations grouped from natural river fragments (67.6\%).
A hierarchical AMOVA conducted over the 15 populations showed that most AFLP diversity was due to variation between individuals within populations (77\%, Table 5A; 79\%, Table 5B; 77\% Table 5C), while that due to differences between populations was lower (17\%, Table 5A; 20\%, Table 5B; $19 \%$, Table 5C).

According to the main principal coordinate analysis of AFLP data for populations, the first three coordinates accounted about $36.6 \%$ of the total genetic variation

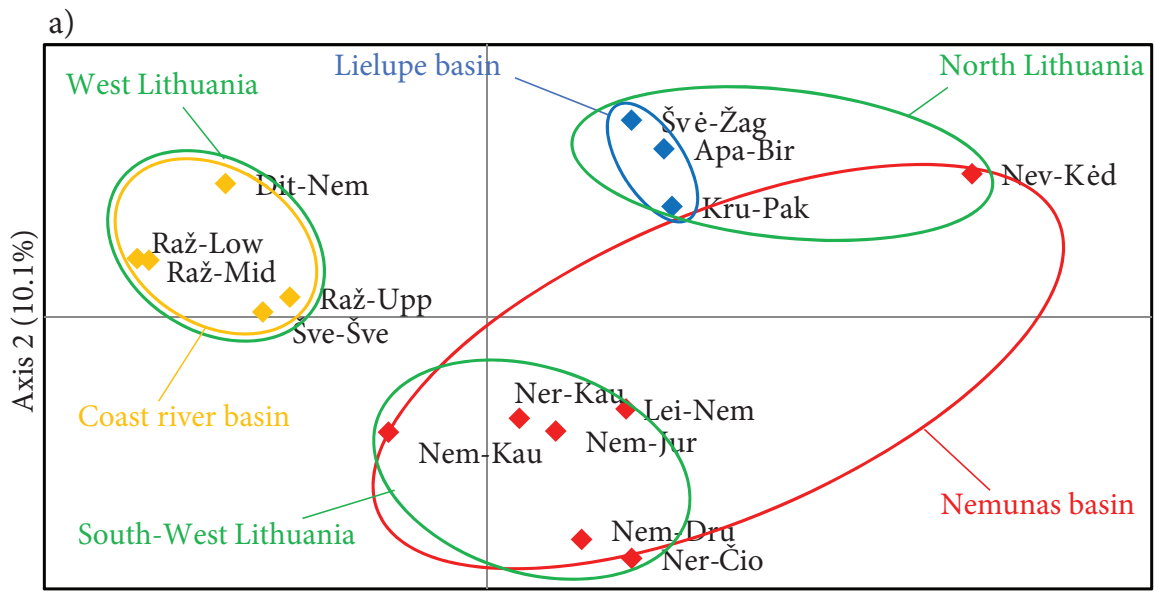

b)

Axis $1(16.8 \%)$

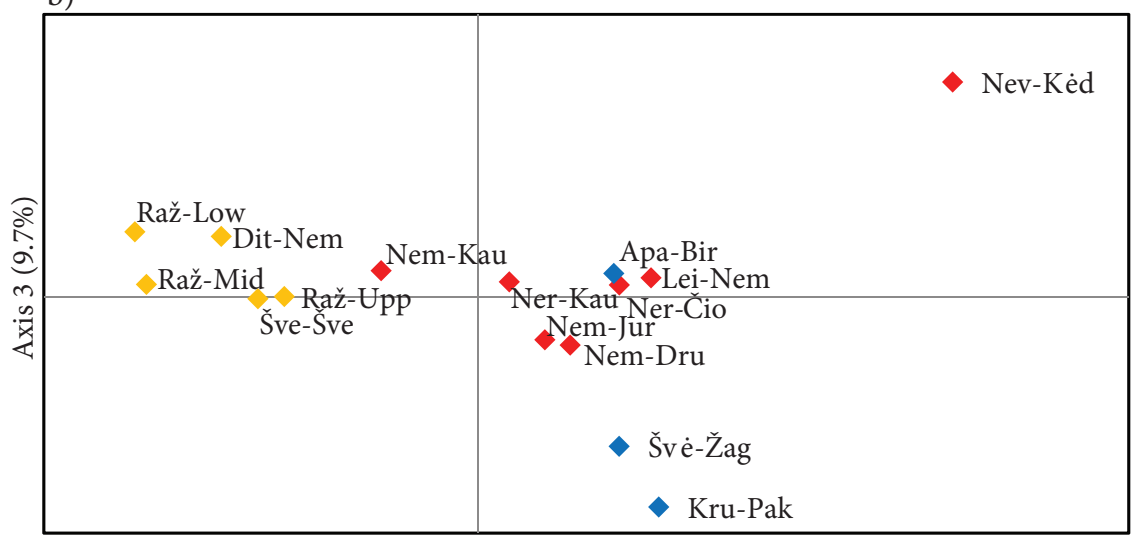

c)

Axis $1(16.8 \%)$

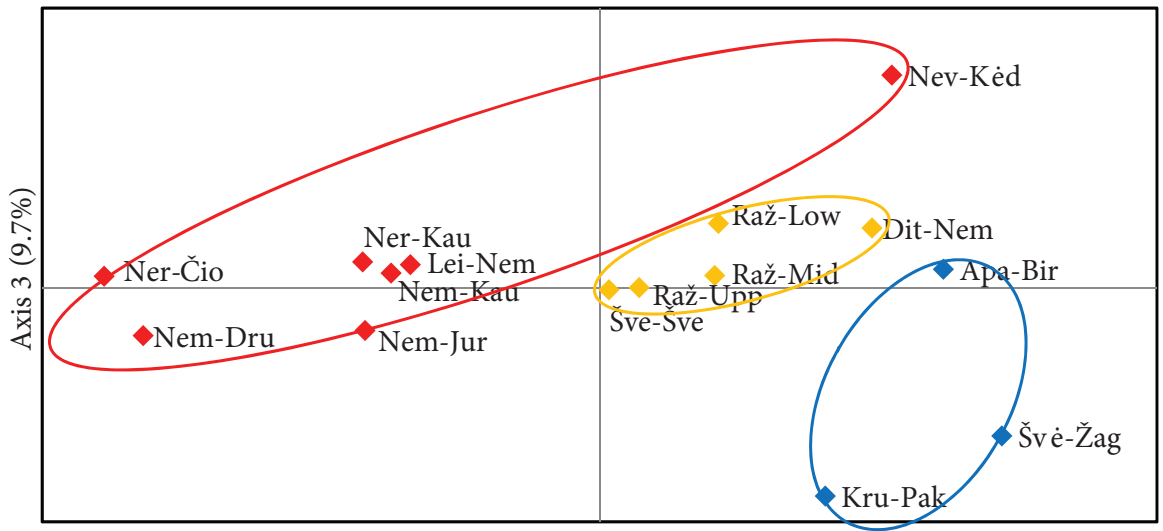

Axis $2(10.1 \%)$

Figure 3. AFLP loci-based clustering patterns of 15 populations of Lithuanian L. salicaria, revealed by principal coordinate analysis (PCoA; principal components 1 vs 2 (a); 1 vs 3 (b); 2 vs 3 (c). Yellow, blue and red colors separate respectively Seaside River basin, Lielupe basin, and Nemunas basin. Green color separate geographic distribution of populations: North Lithuania, South-West Lithuania, and West Lithuania 
(Figure 3), the first, the second, and the third coordinate explained, respectively, $16.8 \%, 10.1 \%$, and $9.7 \%$.

Principal coordinate analysis (PCA) based on scored polymorphisms enabled the differentiation of all populations into three distinct subgroups corresponding different river basins (Figure 3 ).

The first coordinate, which explained $16.8 \%$ of the variation, discriminated populations of Lielupe basin (Šve-Žag, Apa-Bir, Nev-Kèd, Kru-Pak) from populations of Seaside basin populations (Rąž-Upp, Rąž-Mid, Rąž-Low, Šve-Šve, Dit-Nem). The second coordinate, which explained 10.1\% of the variation, clearly discriminated populations of Seaside basin from populations of Nemunas basin (Ner-Kau, Lei-Nem, Nem-Kau, Nem-Jur, Nem-Dru, Ner-Čio). AFLP based principlal coordinates 1 and 3 were less related to different river basins compared to coordinates 1 and 2 or 2 and 3. Defined by PCA, the most distinct population was $\mathrm{Nev}$-Kèd belonging to Nemunas basin.

According to the main principal coordinate analysis of AFLP data the first three coordinates accounted about $19.5 \%$ of the genetic variation of individuals (Figure 4), the first, the second, the third coordinate explained, respectively, $12.6 \%, 3.8 \%$, and $3.1 \%$.

In evaluating population relationships using Bayessian STRUCTURE analysis (Figure 5), a peak of estimated posterior probability at $\mathrm{K}=2$ (Falush et al., 2003) was observed, i.e., the pattern of clustering divided population structure into two clusters (further titled "green" and "white" according to Figure 1). White cluster was prevailing (57.3-83.2\%) among populations of Seaside rivers basin and green cluster was prevailing (54.1-85.0\%) among populations of the Nemunas and Lielupe basins.

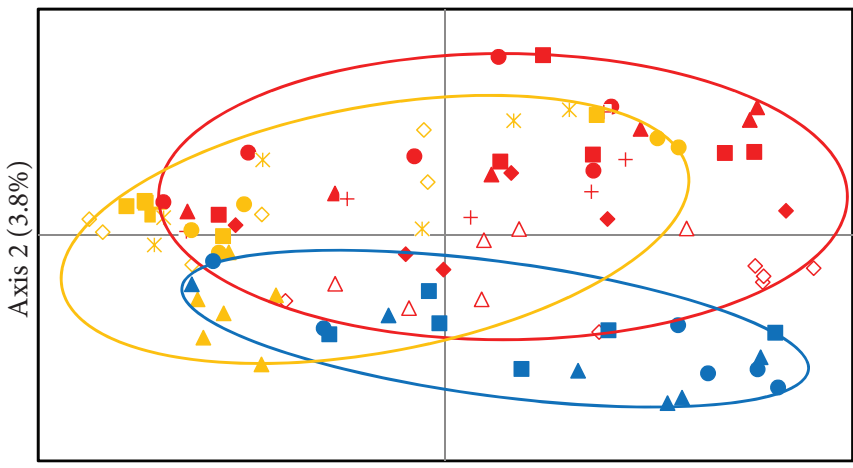

Axis $1(12.6 \%)$

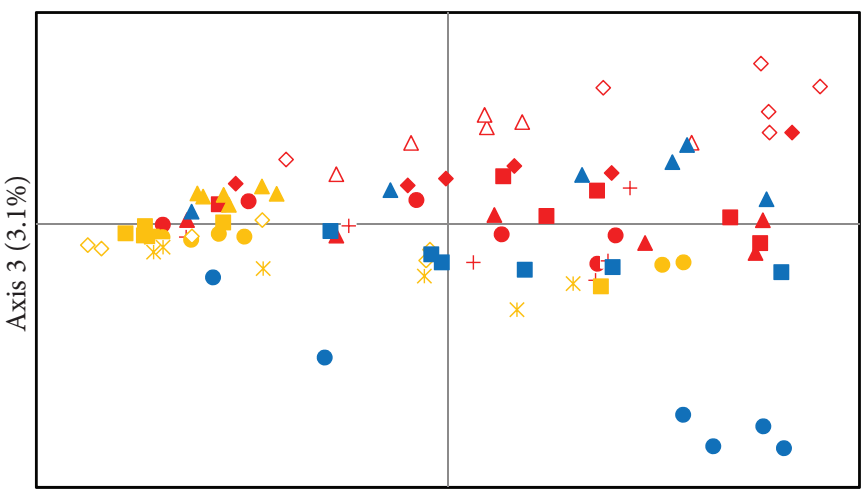

Axis $1(12.6 \%)$

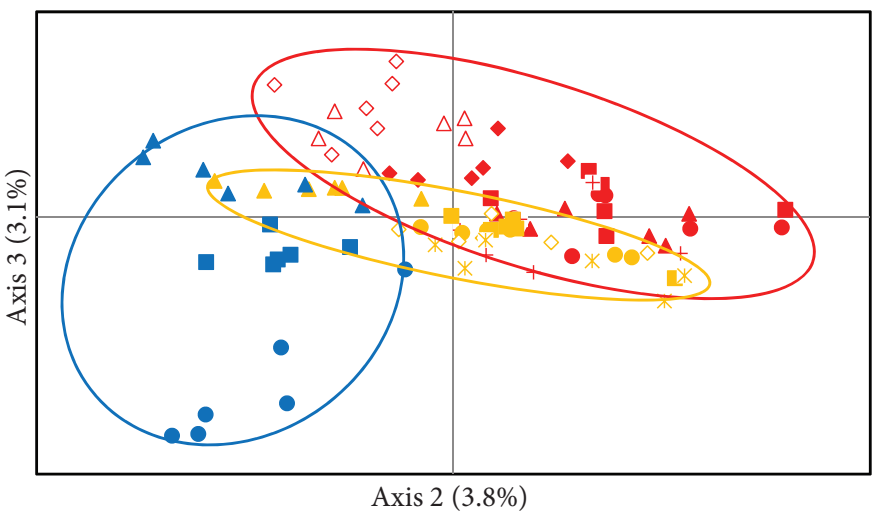

- Nem-Dru

- Ner-Čio

$\triangle$ Ner-Kau

$\bullet$ Nem-Kau

$\diamond \mathrm{Nev-Kèd}$

+ Nem-Jur

$\triangle$ Lei-Nem

- Rąž-Upp

$\diamond$ Rą̌z-Mid

mažz-Low

$\triangle$ Dit-Nem

Š̀ve-Šve

-

\Apa-Bir

- Kru-Pak

- Nem-Dru

- Ner-Čio

$\triangle$ Ner-Kau

-Nem-Kau

$\diamond \mathrm{Nev}-\mathrm{Ke} d$

+ Nem-Jur

$\triangle$ Lei-Nem

- Rąž-Upp

$\diamond$ Rąž-Mid

- Rąž-Low

$\triangle$ Dit-Nem

* Šve-Šve

- Švè-Žag

\Apa-Bir

- Kru-Pak

- Nem-Dru

- Ner-Čio

$\Delta$ Ner-Kau

- Nem-Kau

$\diamond \mathrm{Nev}-\mathrm{Kèd}$

+ Nem-Jur

$\triangle$ Lei-Nem

- Rąž-Upp

$\diamond$ Rąž-Mid

- Rąž-Low

$\triangle$ Dit-Nem

* Šve-Šve

n'̌̀vè-Žag

$\triangle$ Apa-Bir

- Kru-Pak

Figure 4. AFLP loci-based clustering patterns of 90 individuals of Lithuanian L. salicaria revealed by principal coordinate analysis (PCoA; principal components 1 vs $2 ; 1$ vs $3 ; 2$ vs 3 ). Yellow, blue and red colors separate respectively 


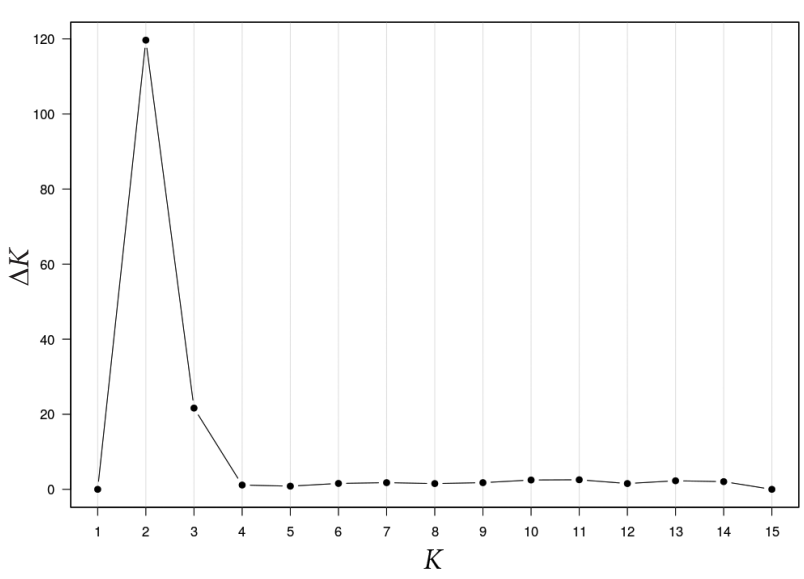

Figure 5. AFLP data-based Bayesian analysis of 15 Lithuanian populations of Lythrum salicaria. $\Delta K$ values for $K$ ranging between 1 and 15

\section{Discussions}

Assumed as geographical center of Europe, Lithuania comprises numerous waterbodies, among which river basins of Nemunas, Lielupe and Seaside are of economic and ecological importance. Nevertheless, riparian species or population genetic diversity remains fragmentaly analyzed. In parallel to present assessment, several pilot studies were performed describing genetic differentiation between Lithuanian populations of some common, invasive or rare macrophytes, like Impatiens glandulifera (Kupcinskiene et al., 2015) I. parviflora (Kupcinskiene et al., 2015), Nuphar lutea (Vyšniauskienè et al., 2020), Phalaris arundinacea (Anderson et al., 2018), Bidens sp. (Vyšniauskienè et al., 2018), Batrachium sp. (Butkuvienè et al., 2020), and Phragmites australis (Naugžemys et al., 2021). As far as we are aware, our study represents the first examination of the genetic diversity of the L. salicaria along Lithuania. No related assessments were done along the other Baltic States.

In most cases Lithuanian populations of macrophytes were examined using ISSR (Vyšniauskienè et al., 2018; Butkuvienè et al., 2020) or SSR markers (Kupcinskiene et al., 2013; Anderson et al., 2018; Vyšniauskienè et al., 2018; Naugžemys et al., 2021). Despite explored for woody species (Frercks et al., 2014), AFLP markers have never been employed for Lithuanian herbaceous plants, at the same time for riparian vegetation. For analyses of $L$. salicaria in Lithuania the AFLP markers were selected as the most used for riparian species research in other countries (Lamote et al., 2002; Fan et al., 2021).

Till our assessment, AFLP based diversity data were available from two studies of $L$. salicaria, both comparing populations of two continents (Houghton-Thompson et al., 2005; Chun et al., 2009). Houghton-Thompson et al. (2005) investigations encompassed 30 populations from N. America and 11 populations from Europe, separating DNA fragments in acrylamide gel. Similarly, another AFLP study that preceded our work, included populations from North America and Western Europe (9 populations), but AFLP has already been performed by capillary electrophoresis. Advanced DNA fractionation determined our choice. Hereby, Chun et al. (2009) group methodology has been chosen. In addition, within implementation of our research some other new data appeared, concerning AFLP based genetic diversity of populations of $L$. salicaria from the mentioned above continents (Middleton et al., 2019). Hereby, till our study, investigations of genetic diversity of L. salicaria in Europe encompassed Western and Central parts: Germany, England, Ireland, Austria, and Finland (Houghton-Thompson et al., 2005), Germany and Switzerland (Chun et al., 2009), Turkey, Spain, Czech Republic, and Finland (Middleton et al., 2019). Despite three independent group analyses (Houghton-Thompson et al., 2005; Chun et al., 2009; Middleton et al., 2019) aimed at comparison of invasive and native populations of $L$. salicaria, results remained inconclusive and controversy: relying on outcomes of one assessment, purple loosestrife populations, introduced into North America, maintained substantial genetic diversity, comparable with native populations (Chun et al., 2009), relying on outcomes of the other study, individual heterozygosity within populations increased curvilinearly northward in Eurasia but decreased northward in North America (Middleton et al., 2019). Such contradictory data showed the expediency of extention of the geographical borders of the sites. There was no explicit answer achieved regarding the universal invasion success of purple loosestrife in North America. Elucidation of mechanisms by which populations differentiate at distinct geographical and temporal scales is still a primary theme in evolutionary biology, invasions in special. Our results are in general agreement with earlier AFLP studies of $L$. salicaria, being the most comparable to Chun et al. (2009) data, obtained by employing the same markers. In that study, the number of polymorphic fragments was 1580 , and in our study 1452 polymorphic fragments were obtained. Polymorphism information content (PIC) ranged between 0.134 and 0.252 in our study, compared to mean value for Europe populations (0.192) and lower for North America populations (0.174) in the mentioned above assessment. Mean number of polymorphic loci per population for Lithuanian case study was $57.2 \%$ (Table 2), while ranges for Eurasia populations were between 56.2\% and 65.4\% (Middleton et al., 2019). Parameteres of genetic diversity of populations of $L$. salicaria were comparable with those obtained for populations of the other Lithuanian aquatic species examined at SSR loci: Phalaris arundinacea - 49.3\% (Anderson et al., 2018) or Phragmites australis - 41.4\% (Naugžemys et al., 2021).

The overall level of genetic variation between populations of $L$. salicaria that we observed $\left(\Phi_{P T}=0.213\right.$; Table 2), was within the range reported for Lithuanian Phragmites australis (Naugžemys et al., 2021), and Nuphar lutea populations (Vyšniauskienè et al., 2020). Employing hierarchic AMOVA, several cases of population grouping were used to determine which of these different groups would give the highest discrimination among populations. 


\subsection{River basins}

There was significant differentiation $\left(\Phi_{R T}=0.054\right.$; $\mathrm{p}<0.001$; Table 5A) between populations of 3 river basins: Nemunas, Seaside, and Lielupè. Mean value of percentage of polymorphic loci (Table 1) of Seaside populations was much lower (47.8\%) than Nemunas basin (60.9\%) and Lielupe basin (64.3\%). It was in agreement with river basin related differentiation of Lithuanian populations of Nuphar luteus (Vyšniauskienè et al., 2020). In addition, our results were in support to genetic data about geographicaly and hydrologicaly isolated basins with Flemish populations of Iris pseudacorus (Lamote et al., 2002) as well as in support to microsatellite data between Spartina alterniflora populations in Japan, with clearly different genotypes of the populations in each out of 4 rivers (Maebara et al., 2020).

\subsection{Geography}

Before our study, sampling of L. salicaria in Europe, was carried out over big scale of Northern latitudes $\left(47^{\circ} 09^{\prime}-\right.$ $52^{\circ} 29^{\prime}$ or $\left.36^{\circ} 52^{\prime}-60^{\circ} 36^{\prime}\right)$ and Eastern longitudes $\left(21^{\circ} 03^{\prime}-\right.$ $24^{\circ} 45^{\prime}$; or $0^{\circ} 37^{\prime}-31^{\circ} 11^{\prime}$; respectively, Chun et al., 2009; Middleton et al., 2019) with very wide variation of climatic and edaphic conditions along transects. Data, concerning genetic diversity of $L$. salicaria at local scale was missing. Hereby, our focus was on very small area populations $\left(54^{\circ} 01^{\prime} 13^{\prime \prime}-56^{\circ} 21^{\prime} 37^{\prime \prime}\right.$ of Northern latitude, $21^{\circ} 03^{\prime}-24^{\circ} 46^{\prime}$ of Eastern longitude). Despite such scale investigations of Lithuanian L. salicaria, significant geographic differentiation (into North Lithuania, West Lithuania, South-West Lithuania) has been observed between populations by hierarchic AMOVA $\left(\Phi_{R T}=0.050 ; \mathrm{p}<0.001\right.$; Table 5B) and PCoA (Figure $3 \mathrm{~A}$ ). The number of percentage of polymorphic loci (\% P) was much lower (47.8\%) for the West Lithuania populations, compared to the South-West (60.8\%) or to the North of Lithuanian populations (63.5\%, Table 2). Geography related differentiation (6.2\%) by hierarchical AMOVA at SSR loci were documented between Lithuanian populations of Juniperus communis, separated into Southern and Northern parts of the country (Vilcinskas et al., 2016). In addition, phenological differences between Northern and Southern parts of Lithuania were observed for the other plant species (Romanovskaja et al., 2009). Temperature and precipitation are well known to strongly influence the survival of any plant, effecting in very complex pathways. Based on several the most important indexes of climate, modest territory of Lithuania is subdivided into 5 climatic regions. Hereby, genetic structure of purple loosestrife populations examined in relatively small territory of Lithuania appeared to be generally like much wider native provenances with different climatic and edaphic conditions. Compared to Lithuanian L. salicaria study, similar extent differentiation (5\%) was observed between populations of L. salicaria of two countries (Chun et al., 2009) or more countries encompasing transect within Europe (Middleton et al., 2019), at the same, differentiation was stronger between both, European and North
American provenances (8\%) or between North America provenances (11\%, Chun et al., 2009).

\subsection{Land use}

Riparian habitats are mosaic of wetlands, grasslands, and woodlands in the stream corridors (Hejda \& de Bello, 2013). Anthropogenic use of aquatic ecosystems causes modifications to inland water bodies: fragmentation of populations in the areas neighbouring rivers and alterations of chemistry (Yoshikava et al., 2015). Prevailing types of neighbouring areas of $L$. salicaria were of agricultural use ( 6 populations), and artificial cover (8 populations), while forest was neighbouring area only for 1 population. According to our data L. salicaria was significantly differentiated among sites of dictinct type of land use. Although, similar to the other investigations the effect was very small $\left(\Phi_{P T}=0.011, \mathrm{p}<0.001\right.$; Table 5, case C). Such genetic processes might be important for small scale evolution. In agreement to our investigations, land use and cover effects on genetics of populations has been documented for some other country grasses (Rudmann-Maurer et al., 2007; Smith et al., 2009) and herbaceous dicots (Reisch \& Poschlod, 2009), however before our assessment such phenomenon was not described for L. salicaria.

\subsection{River regulations}

Within 1950-1990 year period over $80 \%$ of river fragments in Lithuania underwent straightening (Gailiušis et al., 2001). These regulatory modifications had tremendous impact on the landscape, including riparian vegetation (Jablonskis et al., 2007). Before our examination of L. salicaria, scarse information about the impact of river regulation (natural vs. regulated) on the genetic structure of the plant populations was available in the literature (Tero, 2005). In present study, 10 out of 15 populations belonged to the banks of natural river fragments. Significant differentiation $\left(\Phi_{P T}=0.034, \mathrm{p}<0.001\right.$; Table 3) was documented between groups of populations besides natural and regulated fragments of the rivers. For the group of populations besides natural river fragments, mean value of polymorpism at AFLP loci was higher (61.1\%) compared to polymorphism of populations besides regulated river fragments (49.4\%; Table 2$)$. In parallel, performed by us, assessment of populations of Phalaris arundinacea in the basin of Merkys river, comprising the largest protected area of Lithuania has shown that the mean number of polymorphic SSR loci was lower for populations from regulated parts of the river basin compared with natural ones (Anderson et al., 2018). Nearly in the same sites like for Phalaris arundinacea, populations of Phragmites australis did not show differences in genetic diversity between populations growing along natural and straightened river fragments; however, at the local level, 5 populations in straightened river sites had higher genetic diversity values than populations in nearby natural sites within the same river (Naugžemys et al., 2021). Leaf nitrogen concentration of populations 
of Lythrum salicaria was not influenced by riverbed regulations (Krokaite et al., 2019).

Bayesian analysis in STRUCTURE and principal coordinate analysis both suggested considerable differentiation of populations of the Seaside rivers basin from the populations of the Nemunas and Lielupe basins. According to Bayesian analysis, Lithuanian populations of L. salicaria spread over two times or from two genetic groups within evolutionary course. The presence of two genetic clusters in Lithuanian L. salicaria populations is in agreement with the corresponding data examining populations in Germany and Switzerland (Chun et al., 2009), or along the bigger European transect, encompassing Germany, England, Ireland and Finland (Middleton et al., 2019), where also two clusters were documented.

\section{Conclusions}

Our pilot study of Lithuanian populations of L. salicaria extends information concerning AFLP profile for this species in the region of Baltic States.

Genetic variation is an important part of biodiversity and should be considered in conservation of natural genetic resources. Our assessment of $L$. salicaria together with some other studies of species, like Iris pseudacorus or Veronica chamaedrys encourage the use of local material in replantation projects (Lamote et al., 2002).

All populations of Lielupe basin belonged to natural fragments of the rivers, in addition, all populations of this basin were located besides artificial areas, similarly, among populations of Sea coastal basin prevailing type of the river bottom was regulated and prevailing type of neighbouring areas belonged to artificial cover, whereas among Nemunas basin populations prevailing type of the river bottom was natural and neighbouring areas attributed to agricultural use. This indicates that Lithuanian populations of L. salicaria exist in rather different conditions of anthropogenic and other type impacts, and we have detected some traces of molecular signatures of this impact on genetic structure of $L$. salicaria populations. However, the main sources of genetic variation of populations of $L$. salicaria remain to be confirmed and detailed in the future by spatial extention of the current study.

\section{Acknowledgements}

The research was funded by a grant (No. SIT-02/2015) from Research Council of Lithuania.

\section{Author contributions}

Fieldwork, L. J., E. Kr., E. Ku.; laboratory analyses, J. B. Š., E. Kr., L. J., D. S.; statistical analysis and visualization, L. J., T. R., E. Kr., D. S.; writing original draft, L. J., D. S., E. Kr., J. B. Š.; writing - review and editing V. S., D. Ž., A. P., E. Ku.; conceptualization, D. Ž., E. Ku.; funding acquisition, D. Ž.; resources, A. P.

\section{References}

Anderson, J. A., Churchill, G. A., Autrique, J. E., Tanksley, S. D., \& Sorrells, M. E. (1993). Optimizing parental selection for genetic linkage maps. Genome, 36(1), 181-186. https://doi.org/10.1139/g93-024

Anderson, N. O., \& Ascher, P. D. (1993). Male and female fertility of loosestrife (Lythrum) cultivars. Journal of the American Society for Horticultural Science, 118(6), 851-858. https://doi.org/10.21273/JASHS.118.6.851

Anderson, N. O., \& Ascher, P. D. (1995). Style morph frequencies in Minnesota populations of Lythrum (Lythraceae). Sexual Plant Reproduction, 8(2), 105-112. https://doi.org/10.1007/BF00230897

Anderson, N. O., Jocienè, L., Krokaite, E., Rekašius, T., Paulauskas, A., \& Kupčinskienè, E. (2018). Genetic diversity of Phalaris arundinacea populations in relation to river regulation in the Merkys basin, Lithuania. River Research and Applications, 34(4), 300-309. https://doi.org/10.1002/rra.3259

Bradley, C. R., Duignan, C., Preston, S. J., \& Provan, J. (2013). Conservation genetics of Ireland's sole population of the River water crowfoot (Ranunculus fluitans Lam.). Aquatic Botany, 107, 54-58. https://doi.org/10.1016/j.aquabot.2013.01.011

Butkuvienè, J., Sinkevičienė, Z., Naugžemys, D., Patamsytė, J., \& Žvingila, D. (2017). Genetic diversity of Batrachium (Ranunculaceae) species reveals the necessity of their protection in Lithuanian rivers. Aquatic Botany, 142, 61-70. https://doi.org/10.1016/j.aquabot.2017.06.009

Butkuvienè, J., Sinkevičienė, Z., Naugžemys, D., Žvingila, D., Skridaila, A., \& Bobrov, A. A. (2020). Genetic diversity of aquatic Ranunculus (Batrachium, Ranunculaceae) in one river basin caused by hybridization. Plants, 9(11), 1455.

https://doi.org/10.3390/plants9111455

Camacho, J. V., Martínez, A. D. L., Gómez, R. G., \& Sanz, J. M. (2007). A comparative study of five horizontal subsurface flow constructed wetlands using different plant species for domestic waste water treatment. Environmental Technology, 28(12), 1333-1343. https://doi.org/10.1080/09593332808618897

Chun, Y. J., Nason, J. D., \& Moloney, K. A. (2009). Comparison of quantitative and molecular genetic variation of native vs. invasive populations of purple loosestrife (Lythrum salicaria L., Lythraceae). Molecular Ecology, 18(14), 3020-3035. https://doi.org/10.1111/j.1365-294X.2009.04254.x

CORINE Land Cover. (2006). CORINE Land Cover nomenclature conversion to Land Cover Classification system. https:// land.copernicus.eu/eagle/files/eagle-related-projects/pt_clcconversion-to-fao-lccs3_dec2010

Doyle, J. J., \& Doyle, J. L. (1990). Isolation of plant DNA from fresh tissue. Focus, 12(13), 39-40.

Dudgeon, D., Arthington, A. H., Gessner, M. O., Kawabata, Z. I., Knowler, D. J., Lévêque, C., Naiman, R. J., PrieurRichard, A. H., Soto, D., Stiassny, M. L. J., \& Sullivan, C. A. (2006). Freshwater biodiversity: Importance, threats, status and conservation challenges. Biological Reviews, 81(2), 163182. https://doi.org/10.1017/S1464793105006950

Evanno, G., Regnaut, S., \& Goudet, J. (2005). Detecting the number of clusters of individuals using the software STRUCTURE: A simulation study. Molecular Ecology, 14(8), 26112620. https://doi.org/10.1111/j.1365-294X.2005.02553.x

Excoffier, L., \& Lischer, H. E. L. (2010). Arlequin suite ver 3.5: A new series of programs to perform population genetics analyses under Linux and Windows. Molecular Ecology Resources, 10(3), 564-567.

https://doi.org/10.1111/j.1755-0998.2010.02847.x 
Falush, D., Stephens, M., \& Pritchard, K. J. (2003). Inference of population structure using multilocus genotype data: Linked loci and correlated allele frequencies. Genetics, 164(4), 15671587. https://doi.org/10.1093/genetics/164.4.1567

Fan, X. R., Wang, W. C., Chen, L., Li, W., \& Chen, Y. Y. (2021). Genetic relationship among 12 Trapa species/varietas from Yangtze River Basin revealed by AFLP markers. Aquatic Botany, 168, 103320.

https://doi.org/10.1016/j.aquabot.2020.103320

Forsman, A. (2014). Effects of genotypic and phenotypic variation on establishment are important for conservation, invasion, and infection biology. Proceedings of the National Academy of Sciences, 111(1), 302-307.

https://doi.org/10.1073/pnas.1317745111

Frercks, B., Stanys, V., Siksnianiene, J. B., Stepulaitiene, I., Gelvonauskiene, D., Staniene, G., Rugienius, R., \& Siksnianas, T. (2014). Efficiency of AFLP marker attributes in the genetic analysis of sweet cherry cultivars. Journal of Food, Agriculture \& Environment, 12(1), 122-127.

Gailiušis, B., Jablonskis, J., \& Kovalenkoviene, M. (2001). Lithuanian rivers: Hydrography and runoff. Lithuanian Energy Institute, Kaunas.

Gu, C., Ma, L., Wu, Z., Chen, K., \& Wang, Y. (2019). Comparative analyses of chloroplast genomes from 22 Lythraceae species: inferences for phylogenetic relationships and genome evolution within Myrtales. BMC Plant Biology, 19(1), 1-19. https://doi.org/10.1186/s12870-019-1870-3

Guichoux, E., Lagache, L., Wagner, S., Chaumeil, P., Léger, P., Lepais, O., Lepoittevin, C., Malausa, T., Revardel, E., Salin, F., \& Petit, R. J. (2011). Current trends in microsatellite genotyping. Molecular Ecology Resources, 11(4), 591-611. https://doi.org/10.1111/j.1755-0998.2011.03014.x

Hamann, E., \& Puijalon, S. (2013). Biomechanical responses of aquatic plants to aerial conditions. Annals of Botany, 112(9), 1869-1878. https://doi.org/10.1093/aob/mct221

Hejda, M., \& de Bello, F. (2013). Impact of plant invasions on functional diversity in the vegetation of Central Europe. Journal of Vegetation Science, 24(5), 890-897.

https://doi.org/10.1111/jvs.12026

Houghton-Thompson, J., Prince, H. H., Smith, J. J., \& Hancock, J. F. (2005). Evidence of hybridization between Lythrum salicaria (Purple Loosestrife) and L. alatum (Winged Loosestrife) in North America. Annals of Botany, 96(5), 877-885. https://doi.org/10.1093/aob/mci240

Jablonskis, J., Kovalenkovienė, M., \& Tamkevičienė, A. (2007). Channel network of the Lithuanian rivers and small streams. Annales Geographicae, 40(1), 46-56.

Kalusová, V., Chytrý, M., Van Kleunen, M., Mucina, L., Dawson, W., Essl, F., Kreft, H., Pergl, J., Weigelt, P., Winter, M., \& Pyšek, P. (2017). Naturalization of European plants on other continents: The role of donor habitats. Proceedings of the $\mathrm{Na}$ tional Academy of Sciences, 114(52), 13756-13761. https://doi.org/10.1073/pnas.1705487114

Kiesel, J., Guse, B., \& Bormann, H. (2019). Projecting the consequences of climate change on river ecosystems. In S. Sabater, A. Elosegi, \& R. Ludwig (Eds.), Multiple stressors in river ecosystems (pp. 281-301). Elsevier. https://doi.org/10.1016/B978-0-12-811713-2.00016-9

Krokaite, E., Shakeneva, D., Juškaitytė, E., Tomas, R., NemaniūtèGužienè, J., Butkuvienė, J., Patamsytè, J., Rančelienè, V., Vyšiniauskienė, R., Duchovskienė, L., Jocienè, L., Sinkevičienė, Z., Naugžemys, D., Kleizaite, V., Chmura, D., Anderson, N. O., Žvingila, D., \& Kupčinskienė, E. (2019). Nitrogen concentration of the aquatic plant species in relation to land cover type and other variables of the environment. Zemdirbyste-Agriculture, 106(3), 203-212.

https://doi.org/10.13080/z-a.2019.106.026

Kupcinskiene, E., Zybartaite, L., \& Paulauskas, A. (2015). Comparison of genetic diversity of three Impatiens species from Central Europe and Baltic region. Zemdirbyste-Agriculture, 102(1), 87-94. https://doi.org/10.13080/z-a.2015.102.011

Kupcinskiene, E., Zybartaite, L., Janulioniene, R., Zukauskiene, J., \& Paulauskas, A. (2013). Molecular diversity of small balsam populations in relation to site characteristics. Central European Journal of Biology, 8(10), 1048-1061. https://doi.org/10.2478/s11535-013-0228-3

Lambertini, C., Riis, T., Olesen, B., Clayton, J. S., Sorrell, B. K., \& Brix, H. (2010). Genetic diversity in three invasive clonal aquatic species in New Zealand. BMC Genetics, 11(1), 1-18. https://doi.org/10.1186/1471-2156-11-52

Lamote, V., Roldán-Ruiz, I., Coart, E., De Loose, M., \& Van Bockstaele, E. (2002). A study of genetic variation in Iris pseudacorus populations using amplified fragment length polymorphisms (AFLPs). Aquatic Botany, 73(1), 19-31. https://doi.org/10.1016/S0304-3770(02)00006-2

Li, D., \& Yao, S. (2011). Effect of $\mathrm{NaCl}$ on growth and development of Lythrum salicaria L. Guangdong Agricultural Sciences, 38(2), 37-40.

Maebara, Y., Tamaoki, M., Iguchi, Y., Nakahama, N., Hanai, T., Nishino, A., \& Hayasaka, D. (2020). Genetic diversity of invasive Spartina alterniflora Loisel. (Poaceae) introduced unintentionally into Japan and its invasion pathway. Frontiers in Plant Science, 11, 1357.

https://doi.org/10.3389/fpls.2020.556039

Mantel, N. (1967). The detection of disease clustering and a generalized regression approach. Cancer Research, 27(2), 209-220.

Middleton, B. A., Travis, S. E., Kubátová, B., Johnson, D., \& Edwards, K. R. (2019). Morphology and genetics of Lythrum salicaria from latitudinal gradients of the Northern Hemisphere grown in cold and hot common gardens. PloS One, 14(1), e0208300. https://doi.org/10.1371/journal.pone.0208300

Migliore, L., Amendola, A., Cerioli, N. L., Fiori, M., \& Cozzolino, S. (2007). Hormesis in plant (Lythrum salicaria L.): A case study. In A. Kungolos, K. Aravossis, A. Karagiannidis, \& P. Samaras (Eds.), Environmental managenment engineering, planning and economics (pp. 245-250). Grafima Publications.

Migliore, L., Rotini, A., Cerioli, N. L., Cozzolino, S., \& Fiori, M. (2010). Phytotoxic antibiotic sulfadimethoxine elicits a complex hormetic response in the weed Lythrum Salicaria L. Dose-Response, 8(4), 414-427.

https://doi.org/10.2203/dose-response.09-033.Migliore

Naugžemys, D., Lambertini, C., Patamsyte, J., Butkuviene, J., Khasdan, V., \& Zvingila, D. (2021). Genetic diversity patterns in Phragmites australis populations in straightened and in natural river sites in Lithuania. Hydrobiologia, 848, 3317-3330. https://doi.org/10.1007/s10750-021-04606-w

Nawieśniak-Caesar, M., Wilkosz-Mamcarczyk, M., Hernik, J., Gorzelany, J., \& Gorzelany-Dziadkowiec, M. (2019). An integrated approach to river valley revitalisation. Journal of Environmental Engineering and Landscape Management, 27(1), 22-32. https://doi.org/10.3846/jeelm.2019.7481

Nazareno, A. G., Knowles, L. L., Dick, C. W., \& Lohmann, L. G. (2021). By animal, water, or wind: Can dispersal mode predict genetic connectivity in riverine plant species? Frontiers in Plant Science, 12, 626405.

https://doi.org/10.3389/fpls.2021.626405 
Nei, M. (1978). Estimation of average heterozygosity and genetic distance from a small number of individuals. Genetics, 89(3), 583-590. https://doi.org/10.1093/genetics/89.3.583

Peakall, R., \& Smouse, P. E. (2012). GenAlEx 6.5: Genetic analysis in Excel. Population genetic software for teaching and research - an update. Bioinformatics, 28(19), 2537-2539. https://doi.org/10.1093/bioinformatics/bts460

Pritchard, J. K., Stephens, M., \& Donnelly, P. (2000). Inference of population structure using multilocus genotype data. Genetics, 155(2), 945-959. https://doi.org/10.1093/genetics/155.2.945

Rauha, J. P., Remes, S., Heinonen, M., Hopia, A., Kahkonen, M., Kujala, T., Pihlaja, K., Vuorela, H., \& Vuorela, P. (2000). Antimicrobial effects of Finnish plant extracts containing flavonoids and other phenolic compounds. International Journal of Food Microbiology, 56(1), 3-12. https://doi.org/10.1016/S0168-1605(00)00218-X

Reisch, C., \& Poschlod, P. (2009). Land use affects flowering time: Seasonal and genetic differentiation in the grassland plant Scabiosa columbaria. Evolutionary Ecology, 23(5), 753764. https://doi.org/10.1007/s10682-008-9270-4

Richards, C. L., Schrey, A. W., \& Pigliucci, M. (2012). Invasion of diverse habitats by few Japanese knotweed genotypes is correlated with epigenetic differentiation. Ecology Letters, 15(9), 1016-1025. https://doi.org/10.1111/j.1461-0248.2012.01824.x

Richardson, D. M., Holmes, P. M., Esler, K. J., Galatowitsch, S. M., Stromberg, J. C., Kirkman, S. P., Pyšek, P., \& Hobbs, R. J. (2007). Riparian vegetation: Degradation, alien plant invasions, and restoration prospects. Diversity and Distributions, 13(1), 126-139.

https://doi.org/10.1111/j.1366-9516.2006.00314.X

Riis, T., Kelly-Quinn, M., Aguiar, F. C., Manolaki, P., Bruno, D., Bejarano, M. D., Clerici, N., Fernandes, M. R., Franco, J. C., Pettit, N., Portela, A. P., Tammeorg, O., Tammeorg, P., Rodríguez-González, P. M., \& Dufour, S. (2020). Global overview of ecosystem services provided by riparian vegetation. BioScience, 70(6), 501-514. https://doi.org/10.1093/biosci/biaa041

Romanovskaja, D., Kalvane, G., Briede, A., \& Bakšienė, E. (2009). The influence of climate warming on the changes of the length of phenological seasons in Lithuania and Latvia. Žemdirbyste-Agriculture, 96(4), 218-231.

Rudmann-Maurer, K., Weyand, A., Fischer, M., \& Stöcklin, J. (2007). Microsatellite diversity of the agriculturally important alpine grass Poa alpina in relation to land use and natural environment. Annals of Botany, 100(6), 1249-1258. https://doi.org/10.1093/aob/mcm203

Smith, S. E., Arredondo, T., Aguiar, M., Huber-Sannwald, E., Alpuche, A., Aguado, A., Grageda, O. A., Halbrook, K., \& Bottini, C. (2009). Fine-scale spatial genetic structure in perennial grasses in three environments. Rangeland Ecology \& Management, 62(4), 356-363. https://doi.org/10.2111/08-159.1

Souza, H. A. V., Muller, L. A. C., Brandão, R. L., \& Lovato, M. B. (2012). Isolation of high quality and polysaccharide-free DNA from leaves of Dimorphandra mollis (Leguminosae), a tree from the Brazilian Cerrado. Genetics and Molecular Research, 11(1), 756-764. https://doi.org/10.4238/2012.March.22.6
Stella, J. C., \& Bendix, J. (2019). Multiple stressors in riparian ecosystems. In S. Sabater, A. Elosegi, \& R. Ludwig (Eds.), Multiple stressors in river ecosystems: Status, impacts and prospects for the future (pp. 81-110). Elsevier. https://doi.org/10.1016/B978-0-12-811713-2.00005-4

Tero, N. (2005). Genetic structure at different spatial scales in metapopulations of Silene tatarica [Ph.D. dissertation]. University of Oulu.

The Local Food-Nutraceuticals Consortium. (2005). Understanding local Mediterranean diets: A multidisciplinary pharmacological and ethnobotanical approach. Pharmacological Research, 52(4), 353-366. https://doi.org/10.1016/j.phrs.2005.06.005

Thompson, D. Q., Stuckey, R. L., \& Thompson, E. B. (1987). Spread, impact, and control of purple loosestrife (Lythrum salicaria) in North American wetlands (Research Report No. 2). USDI, U.S. Fish and Wildlife Service, Washington, D.C., USA.

Vilcinskas, R., Jociene, L., Rekasius, T., Marozas, V., Paulauskas, A., \& Kupcinskiene, E. (2016). Genetic diversity of Lithuanian populations of Juniperus communis L. in relation to abiotic and biotic factors. Dendrobiology, 76, 61-71. https://doi.org/10.12657/denbio.076.006

Vos, P., Hogers, R., Bleeker, M., Reijans, M., Lee, T., Hornes, M., Frijters, A., Pot, J., Peleman, J., Kuiper, M., \& Zabeau, M. (1995). AFLP: A new technique for DNA fingerprinting. Nucleic Acids Research, 23(21), 4407-4414.

https://doi.org/10.1093/nar/23.21.4407

Vyšniauskienė, R., Rančelienė, V., Naugžemys, D., Patamsytė, J., Sinkevičienè, Z., Butkuvienè, J., \& Žvingila, D. (2018). Genetic diversity of populations of Bidens genera invasive and native species in Lithuania. Zemdirbyste-Agriculture, 105(2), 183-190. https://doi.org/10.13080/z-a.2018.105.024

Vyšniauskienė, R., Rančelienė, V., Naugžemys, D., RudaitytèLukošienè, E., Patamsytė, J., Butkauskas, D., Kupčinskienė, E., \& Žvingila, D. (2020). Genetic diversity of Nuphar lutea in Lithuanian river populations. Aquatic Botany, 161, 103173. https://doi.org/10.1016/j.aquabot.2019.103173

Wennersten, L., \& Forsman, A. (2012). Population-level consequences of polymorphism, plasticity and randomized phenotype switching: A review of predictions. Biological Reviews, 87(3), 756-767. https://doi.org/10.1111/j.1469-185X.2012.00231.x

Yeh, F. C., Yang, R. C., \& Boyle, T. (1999). POPGENE version 1.31: Microsoft Windows - based freeware for population genetic analysis, quick user guide. Center for International Forestry Research, University of Alberta, Edmonton, Alberta, Canada.

Yoshikawa, S., Takahashi, H., Sasada, Y., \& Mochizuki, H. (2015). Impact of land use on nitrogen concentration in groundwater and river water. Soil Science and Plant Nutrition, 61(6), 898-909. https://doi.org/10.1080/00380768.2015.1104521

Zviedre, E., Vìtola, I., Vizule-Kahovska, L., \& Upena, I. (2015). Evaluation of phytobenthos and macrophytes of the inland surface waters and ecological status defined by macrophyte reference index (Report, Part II, Rivers). Latvian Environment, Geology and Meteorology Centre. 